\title{
Labels layout of cats and dogs food sold in Brazil and their national regulation adequacy
}

\author{
Layouts de rotulagem de alimentos completos para cães e gatos comercializados no Brasil e \\ adequação quanto à legislação nacional
}

\author{
Karina Koerich de Souza $^{\mathrm{I}}$ Karina Merini Tonon ${ }^{\mathrm{I}}$ Vildes Maria Scussel $^{\mathrm{I}}$
}

\begin{abstract}
Due to the increasing of the pet foods marketing and the need to establish standards for quality and registration purposes, a study was conducted to evaluate the information on the package labels of 64 dogs and cats complete dry foods commercialized in Brazil and compare them to current regulation of the sector. From the total labels analyzed, all of them (100\%) presented unconformity for at least one of the items evaluated. The highest rate of non-conformity was observed in the presentation of illustrations and phrases that induced the use of the product based on the false concept of advantage or animal health security (47\%), leading to the misunderstanding of the owners. The results demonstrate a deficiency of the manufacturing companies regarding the labeling adequacy to the pet food regulation, as well as indicate a lack of rigorous enforcement by the agencies.
\end{abstract}

Key words: pet food, dogs, cats, labels, regulation.

\section{RESUMO}

Considerando a diversidade de tipos, composição e informações atrativas presentes nas embalagens de alimentos para cães e gatos existentes no mercado, foi realizado um estudo para avaliar as informações contidas na rotulagem de 64 alimentos completos secos para esses animais comercializados em diferentes regióes do Brasil e sua conformação com as informações obrigatórias exigidas pela legislação brasileira. Do total de 64 rótulos analisados, 100\% tiveram discordância para pelo menos um dos itens avaliados. A maior frequência de não conformidades observada foi a apresentação de ilustrações e frases inadequadas que dão ideia de vantagem ou segurança (47\%), induzindo ao entendimento equivocado dos proprietários. Os resultados demonstraram deficiência das empresas fabricantes quanto ao cumprimento

\begin{abstract}
e em ações para adequação da rotulagem de seus produtos às normas vigentes, além de falta de fiscalização rigorosa por parte das agências.
\end{abstract} Palavras-chave: alimentos para animais, cão, gato,
rotulagem, legislação.

\section{INTRODUCTION}

A considerable increase in the marketing of pet foods has been observed in recent decades. The market-oriented products for pets, has become a very promising investment, since this niche corresponds to $80 \%$ of all products in order to meet the demands of the consumers. The great development of this market is mainly due to the large population of dogs and cats living in confinement and it is estimated that in Brazil there are 29 and 14 million dogs and cats, respectively (SIMAO \& SCUSSEL, 2008; ANFALPET, 2011). The Brazilian Ministry of Agriculture, Livestock and Supply (MAPA) is responsible for regulating the inspection and supervision of products intended for animal feed, standardizing the labeling information and obligations of the manufacturers of these foods (BRAZIL, 2003, 2009). While recent federal regulation may change some aspects over the next few years, an understanding of who regulates pet foods and the basic rules governing the manufacture, labeling, and distribution of pet foods as they exist today is necessary to appreciate the extensive controls that are placed on the industry.

'Laboratório de Micotoxinas e outros Contaminantes (LABMICO), Departamento Ciência dos Alimentos, Centro de Ciências Agrárias, Universidade Federal de Santa Catarina (UFSC), R. Admar Gonzaga, 1346, 88034-001, Itacorubi, Florianópolis, SC, Brasil. E-mail: kakoerich@yahoo.com.br. *Autor para correspondência. 
In 2009, two Normative Instructions (NI) established by the MAPA (BRAZIL, 2009) regulated the procedures for registration of establishments and products for animal feed, its labeling and advertising, in addition to the exemption from registration of products for feeding pets. On the other hand, the Ordinance n. 2658 of the Ministry of Justice and Decree n. 4680 , established the right to information on food and ingredients for human and animal consumption, related to the presence of genetically modified organisms (GMO) (BRAZIL, 2003).

There is a lack of information regarding the adequacy of pet food labeling in Brazil. Only a work carried out by the same group in 2011 reported nonconformities in Brazilian foods for dogs (de SOUZA KOERICH et al., 2011). Considering the diversity of types, composition and information present in attractive packaging of pet food in the market, a study was conducted to evaluate the information in the labeling of complete dry food for dogs and cats sold in different regions of Brazil and its adherence to regulation required by Brazilian law.

\section{MATERIAL AND METHODS}

Samples: collected by free access, intentional sampling in supermarkets, agricultural households, veterinary clinics and pet stores, 64 samples of complete dry food for dogs and cats packages of different brands commercialized in Brazil, from three Regions: (a) Southern: 41; (b) North: 19 and (c) Southeast: 4. Out of the total, 31,30 and 3 packages were produced in Southeast, South and Midwest Region, respectively. In total, 48 ( $75 \%$ ) were for dogs and 16 samples (25\%) for cats, and about age, $13(20 \%)$ intended for puppies, 44 (69\%) for adult animals and 7 (11\%) for seniors.

The dogs and cats dry food packages were evaluated in several aspects related to compliance with Brazilian law by the manufacturers as to their suitability. The regulation were: (a) NI n.15 of 26/05/2009 - provides the procedures for registration of establishments and products intended for animal feed, (b) NI n.30 of 05/08/ 2009 - establishes criteria and procedures for the registration of products for the labeling, advertising and the exemption from registration of products intended for pet animals, (c) Decree n.4680 of 24/04/ 2003 - regulates the right to information about food and food ingredients intended for human consumption or feed containing, or produced from GMO, subject to compliance with other applicable standards and (d) Ordinance n. 2658 of 22/12/2003 - regulates the use of transgenic symbol mentioned in Art 2 of Decree n. 4680.
The consumer should be informed about the kind donor of the gene in the place reserved for the identification of ingredients. The symbol should appear in the main panel, highlight and color contrast to ensure the correct visibility.

The individual analysis of each package included the items (BRAZIL, 2009a;b): correct classification of the product according to the MAPA regulation (complete and specific food); clear indication of use, species, stage and type of animal and instructions for supply or use of the product; determination of basic composition and levels of security and guarantees minimum declared the product adequately described; ingredient necessarily inscribed in the field emphasized basic composition and reported their level of inclusion and featured nutrient levels stated in the warranty; additives declaration in the basic composition of the product at the end of the list of ingredients; storage conditions and time of consumption; date of manufacture and expiry date, being the day, month and year in Arabic numerals; batch product identification legibly, indelibly marked and visible; vitamins and trace levels declared enrichment in the field to a minimum; information of basic composition, level of assurance, statement of use, animal species and category to which they relate, how to use and care grouped together; manufacturer's information; manufacturing establishment with different plants according to the criteria for registration and identification of units with letters; official stamp of inspection; expressions "Brazilian Industry" and "Use prohibited in ruminant feed"; contain vocabulary, terminology, statements, signs, names, slogans, logos, seals, emblems, illustrations, photos, drawings or other graphical representations that can make the information untrue, inaccurate, insufficient, or that might lead consumers to mistake, error, confusion, deception or false understanding, also suggest treatment, prevention, diagnosis, alleviation, cure, pharmacological, immunological action, therapeutic activity or relationship with poisoning, infections, disorders, diseases, signs, symptoms, syndromes or anatomical data. Labels also were evaluated if the mandatory information was printed in a contrasting color to the background and font size legible and cannot be located in the folds of packaging seams or difficult to see anywhere.

\section{RESULTS AND DISCUSSION}

Out of the 64 labels evaluated, $100 \%$ showed some non-conformity to the Regulation items accessed (BRAZIL, 2003a;b; BRAZIL 2009a;b). They were related 
to the product rating, the food use guarantees, composition and guarantees, also regarding to the manufacturer's information, as model of the official inspection and enforcement stamp, the binding expressions, GMO symbol and misunderstanding and/ or confusion (Table 1).

Product rating: according to the MAPA regulation, labeling of $8(12.5 \%)$ incorrectly classified the type of food, as specific food rather than complete food for dogs. For the purposes of NI n.30, a specific food product is compose of ingredients or raw materials or additives intended exclusively for feeding pets with the purpose of pleasure or reward and that is not characterized as whole food and can have properties specific.

Use guarantees: clear indication of use, species, stage and type of animal and instructions for supply or use of the product only one sample did not clearly indicate the stage to which the food was intended. Storage conditions and period of consumption $-100 \%$ of the labels indicated storage conditions. Date of manufacture and expiry date, being the day, month and year in $11(17 \%)$ samples did not indicate expiry date in Arabic numerals, but as period of consumption. Even, a sample indicated two forms of validity, and that they did not show the same expiration date of the product. About batch product identification, $12(18.7 \%)$ samples didn't indicate this information.

Composition and guarantees: determination of basic composition and levels of security and guarantees minimum declared the product adequately described only $2(3 \%)$ of the labels showed no minimum guarantees described in $\mathrm{mg} \mathrm{kg}^{-1}$ or $\mathrm{g} \mathrm{kg}^{-1}$, only a

Table 1 - Labels rating of dogs and cats complete dry food packaging sold in Brazil and their description of non-compliances based on the current Regulation for pet food labeling.

\begin{tabular}{|c|c|c|}
\hline \multirow{2}{*}{ Brazilian Regulation $^{\mathrm{a}}$} & \multirow{2}{*}{ Description of non-conformities } & \multirow[b]{2}{*}{ Number of labels $(\%)$} \\
\hline & & \\
\hline NI 30 art.43 & $\begin{array}{l}\text { Contain expressions and illustrations that can induced consumers to mistake, error, } \\
\text { confusion, deception or false understanding of the owner }\end{array}$ & $30(47)$ \\
\hline NI 30 art.25 & $\begin{array}{l}\text { Do not facilitate the visualization of information requirements (small letters, located } \\
\text { in folds and seams of the package) }\end{array}$ & $17(37.5)$ \\
\hline NI 30 art.32 & Labels inscribed nutrients, but did not report the levels of security & $14(21.8)$ \\
\hline NI 30 art.51 & $\begin{array}{l}\text { Do not comply with the criteria for registration and identification of units with letters } \\
\text { in manufacturing establishment with different plants }\end{array}$ & $12(19)$ \\
\hline NI 30 art.9/38 & Do not identify the batch of product & $12(19)$ \\
\hline NI 30 art.37 & Do not indicate expiry date in Arabic numerals & $11(17)$ \\
\hline $\begin{array}{l}\text { Ordinance n. } 2658 \text { art. } 1 \\
\text { Decree n. } 4680 \text { art. } 1,2\end{array}$ & $\begin{array}{l}\text { Do not contain the symbol on the labeling of GMO in complete foods produced from } \\
\text { genetically modified organisms listed in the identification of ingredients (the gene } \\
\text { donor species mentioned) }\end{array}$ & $10(16)$ \\
\hline NI 30 art.9 & Wrong specification of the model the official stamp of the inspection and supervision & $10(15.6)$ \\
\hline NI 30 art.43 & $\begin{array}{l}\text { Label indicates the addition of vitamin and mineral premix formulation, but does not } \\
\text { state the level of assurance in the field enrichment }\end{array}$ & $9(14)$ \\
\hline NI 30 art.25 & $\begin{array}{l}\text { Do not contain information grouped basic composition assurance levels, an indication } \\
\text { of use, animal species and category to which they relate, and how to care and use } \\
\text { restrictions }\end{array}$ & $9(14)$ \\
\hline NI 30 art.9 & incorrectly classified the type of food according to the MAPA regulation & $8(12.5)$ \\
\hline NI 30 art.51 & $\begin{array}{l}\text { Do not include the phrase: "the manufacturing establishment is identified by the letter } \\
\text { corresponding to the date of manufacture of each branch" in the manufacturing } \\
\text { establishments having different branches }\end{array}$ & $8(12.5)$ \\
\hline NI 30 art.9 & Do not have the expression "Brazilian Industry" & $8(12.5)$ \\
\hline $\begin{array}{l}\text { NI } 15 \text { art.20; } \\
\text { NI } 30 \text { art.14 }\end{array}$ & Do not indicate vitamin $\mathrm{E}$ in $\mathrm{IU} \mathrm{kg}{ }^{-1}$ and vitamin B12 in $\mu \mathrm{g} \mathrm{kg}^{-1}$ & $6(9.4)$ \\
\hline NI 30 art.15/30 & Declaring additives in the field of enrichment & $4(6.25)$ \\
\hline $\begin{array}{l}\text { NI } 15 \text { art.20 } \\
\text { NI } 30 \text { art.14 }\end{array}$ & Do not present level of assurance expressed in $\mathrm{mg} \mathrm{kg}^{-1}$ or $\mathrm{g} \mathrm{kg}^{-1}$ & $2(3)$ \\
\hline
\end{tabular}

${ }^{a}$ Regulation n. 4.680, 24/04/2003

Ordinance n. 2658, 22/12/2003

NI n. $15,26 / 05 / 2009$

NI n.30, 05/08/2009.

Ciência Rural, v.43, n.2, fev, 2013. 
percentage $(\%)$, in disagree with regulation. About the ingredient necessarily described in the field emphasized basic composition and reported their level of inclusion and featured nutrient levels stated in the warranty, 14 $(21.8 \%)$ labels inscribed nutrients, but did not report the levels of security. All additives should be declared in the basic composition of the product at the end of the list of ingredients, but in $4(6.25 \%)$ of the labels were incorrectly described in the field of enrichment. With respect to levels of assurance, 9 (14\%) did not report levels of assurance in the field enrichment, even with the addition of vitamins and mineral premix base composition (product formulation) and 19 (15.6\%) indicated but not quantified adding the minimum values of inclusion. In $9.4 \%$ labels, vitamins A, D and $\mathrm{E}$ were not guaranteed in IU kg-1 and vitamin B12 in $\mu \mathrm{g} \mathrm{kg}^{-1}$. About information care grouped together, 9 (14\%) labels were non-conformities.

Manufacturer's information: 13 (20\%) labels did not comply with the criteria for registration and identification of units with letters in manufacturing establishment with different plants, 7 (11\%) had no identification letter spelled after the date of manufacture for identifying the location of the factory where the product was manufactured and $8(12.5 \%)$ not had included the phrase: "the manufacturing establishment is identified by the letter corresponding with the date of manufacture."

Model of inspection and enforcement official stamp: 19 (15.6\%) of the labels were incorrect with the requirements of the regulation (NI No.30).

Binding expressions: 8 (12.5\%) of the labels did not have the expression "Brazilian Industry" and $100 \%$ indicated the expression "use prohibited in ruminant feed".

GMO symbol: 10 (15.6\%) of the labels did not contain the GMO symbol foods intended for animal consumption that are produced from genetically modified organisms, but also the obligation to inform the consumer about the kind of gene donor in the place reserved for the identification ingredients (BRAZIL, 2003a). It is to assess if all products that do not have these symbols on the labels really do not use GMO products in their composition, which can only be obtained through analysis.

Misunderstanding and or confusion: regarding the display of expressions that can induce consumers to mistake, error, confusion, deception or false understanding, $30(46.8 \%)$ of the labels had illustrations that induced the use of the product based on the false concept of advantage or animal health security and $10(15.6 \%)$ contained dubious phrases that made the misinformation and lead the owner to false understanding.
In the general arrangement of the required information, there was a lack of standardization in the distribution of the information required, not following the grouped of information as required by regulations. Information labels of $8(12.5 \%)$ were available at different locations of the package, and not as visible, and prioritize calls and business figures and 24 (37.5\%) of the labels did not facilitate the visualization of information requirements (small letters, located in folds and seams of the package).

\section{CONCLUSION}

The non-conformities on the labels of complete dry foods for dogs and cats regarding regulations demonstrated deficiency of manufacturers in take actions to fit the labeling of their products to current standards, and lack of enforcement agencies into meet these standards. It is necessary that the pet food producers suit to the new regulations in order to avoid consumers (owners) to misinformation and / or ambiguity of understanding.

\section{REFERENCES}

ANFALPET (Associação Nacional dos Fabricantes de Alimentos para Animais de Estimação). São Paulo, SP, 2011. Available from: <http:// www.anfalpet.org.br>. Accessed: Aug. 15, 2011.

BRAZIL. Decreto n.4.680 de 24 de abril de 2003a. D.O.U., Brasília, 28 de abril de 2003. Available from: <http:// sistemasweb.agricultura.gov.br>. Accessed: Jul. 10, 2011.

BRAZIL. Ministério da Justiça. Portaria n.2.658 de 22 de dezembro de 2003b. D.O.U., Brasília, 26 de dezembro de 2003. Available from: <http://sistemasweb.agricultura.gov.br>. Accessed: Jul. 10, 2011.

BRAZIL. Ministério da Agricultura, Pecuária e Abastecimento. Instrução Normativa n.15 de 26 de maio de 2009. D.O.U., Brasilia, 28 de maio de 2009a. Available from: <http:// sistemasweb.agricultura.gov.br>. Accessed: Jul. 10, 2011.

BRAZIL. Ministério da Agricultura, Pecuária e Abastecimento. Instrução Normativa n.30 de 05 de agosto de 2009. D.O.U., Brasilia, 07 de agosto de 2009b. Available from: <http:// sistemasweb.agricultura.gov.br>. Accessed: Jul. 10, 2011.

DE SOUZA, K. et al. Evaluation of dogs and cats pathologies and their relation to mycotoxins. In: ANNUAL WORLD SMALL ANIMALL VETERINARY ASSOCIATION CONGRESS, 35, 2010, Geneve. Proceedings...Geneve: WSAVA, 2010. p.100.

SIMAO, V.; SCUSSEL, V.M. Qualidade na produção de rações e ingredientes para pets. In: SCUSSEL V.M. et al. Atualidades em micotoxinas e armazenagem qualitativa de grãos II. Florianópolis: ABMAG, 2008. Cap.3, p.101-105. 